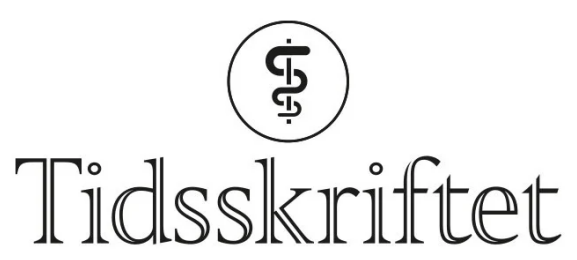

DEN NORSKE LEGEFORENING

\title{
Bjørn Enstad
}

MINNEORD

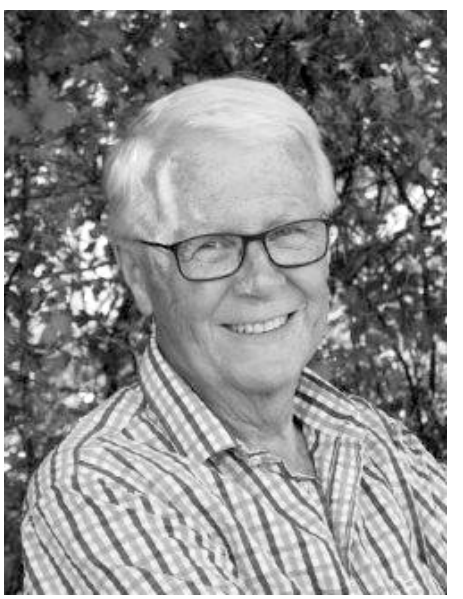

Bjørn ble vår kollega ved Klinikk for psykisk helsevern og rus i april 2003. I søknaden skrev han om et "utfordrende og spennende legeliv i inn- og utland». Slike knappe og konsise setninger, som samtidig rommet et spenn av livsvisdom, var Bjørns spesialitet.

Hans legeliv startet med medisinstudier i Wien. Han fortalte hvordan han spent tok toget sammen medstudent Terje Vigen og overvintret i en iskald leilighet. Om sachertorte på kafeen ved Freud-museet og forelesere som holocaustoverlever Viktor Frankl.

Bjørn brakte med seg et internasjonalt perspektiv til Levanger og Stjørdal. Han hadde arbeidet både i Afrika og Asia og stått overfor ekstremt krevende utfordringer både som menneske og fagperson. Da han fortalte om fødsler på distriktslegekontoret i Lierne, var det ikke utryggheten over å være langt unna sykehuset han snakket om, men fascinasjonen over livets under.

Slik var han også overfor oss. Han brakte med seg en spesiell ro, han klarte å knytte teori og praksis sammen, og han hadde et helt særegent talent for å se når vi trengte hjelp. Lenge før vi skjønte det selv. Da bare var han der for oss. Akkurat passe mye, akkurat tett nok på til at vi lærte av det.

På tre kontinenter gjorde Bjørn en forskjell for pasienter, medmennesker og oss som var så heldige å være kollegene hans. Det fortsatte han med også da han fikk de første symptomene på kreftsykdom. Det sto han ved gjennom tøff behandling og varige ettervirkninger frem til han ble pensjonist. Bjørn var klar over at familien han satte så høyt, hadde betalt en pris for at han hadde brukt mye tid og krefter på å hjelpe andre. Selv om 
han visste han hadde en sykdom som før eller siden ville ramme igjen, fikk han heldigvis gode år som pensjonist sammen familien. Ikke det at han sluttet å hjelpe oss og andre som stadig trengte det, nå var vi så heldige at vi fikk gode samtaler med både ham og Svanhild hjemme hos dem i Fossingtrøa.

Da tilbakefallet kom, sørget han for å forberede oss alle på at slutten nærmet seg. Som han sa det selv - han skulle hjem. Men han rakk å lære oss mye om litteratur, mestring, bivirkninger og hvor viktig det er å tenke livskvalitet.

Kjære Bjørn, også vi som ikke har et like nært forhold til Gud som du hadde - vi ønsker deg nå vel hjem.

På vegne av alle kolleger ved Klinikk for psykisk helsevern og rus

Publisert: 19. mars 2018. Tidsskr Nor Legeforen. DOI: 10.4045/tidsskr.18.0127

(C) Tidsskrift for Den norske legeforening 2023. Lastet ned fra tidsskriftet.no 26. april 2023. 